\section{Institutional change and political decision- making in the creation of the Brazilian National Health Surveillance Agency}

\author{
Mudança institucional e processo de decisão \\ política: a criação da Agência Nacional de \\ Vigilância Sanitária
}

\author{
${ }^{1}$ Agência Nacional de Saúde \\ Suplementar, Ministério da \\ Saúde, Rio de Janeiro, Brasil. \\ 2 Escola Nacional de Saúde \\ Pública Sergio Arouca, \\ Fundação Oswaldo Cruz, \\ Rio de Janeiro, Brasil. \\ Correspondence \\ M. F. Piovesan \\ Agência Nacional de \\ Saúde Suplementar \\ Ministério da Saúde. \\ Av. Augusto Severo 84, \\ Rio de Janeiro, $R J$ \\ 20021-040, Brasil \\ marcia.piovesan@ensp.fiocruz.br
}

\begin{abstract}
This article examines the decision-making process that led to the creation of the Brazilian $\mathrm{Na}$ tional Health Surveillance Agency (ANVISA) in 1999. The authors begin by discussing the history of the Agency's predecessor, the Health Surveillance Secretariat, and the need for its modernization to adjust the quality of the products under its control to domestic and international demands. From the theoretical perspective of neo-institutionalism, the article goes on to analyze the social and political context surrounding the debate on the proposed alternatives to adjust Health Surveillance to new rules in line with such requirements, focusing especially on the formulation of the new policy, the decisionmaking arena, and the actors with specific interests in the sector. The research drew on extensive documentary and media material, plus interviews with key actors. The article concludes that a determinant factor for the creation of ANVISA was the favorable domestic political context, fostering a positive correlation of forces that (in an extremely short timeframe, 1998-1999) allowed the creation of the first regulatory agency in the social policies area in Brazil.
\end{abstract}

Health Surveillance; National Health Surveillance Agency; Public Policies
Márcia Franke Piovesan 1

Maria Eliana Labra 2

\section{Introduction}

The aim of this article is to analyze the political/ institutional context that gave rise to the Brazilian National Health Surveillance Agency (Agência Nacional de Vigiância Sanitária - ANVISA) in the 1990s, especially 1998 and 1999, when the final decisions were made and the respective legislation was enacted.

A brief history of the Federal level of Health Surveillance in Brazil shows that it was inevitably characterized by technical and political gaps and impediments, which constrained its action over time and refueled the claims of its purported inoperability. Blatant problems resulted from its inaction at many stages in this historical process, reverberating in the mass media and causing public outcry, with no responses that might have tended to set rules for the power game, i.e., policy institutionalization and a corresponding search for solutions.

Against this backdrop, the point of departure for our research was the following question: what were the factors or events that influenced the decision to solve such a longstanding problem, in the form of a public policy drafted and approved in such an usually short timeframe?

The analysis focuses on the creation of ANVISA 1, based on a neo-institutionalist approach, emphasizing the way by which a given institutional configuration shapes the interactions between stakeholders and influences the 
public policy results. By shaping the stakeholders' strategies and goals, mediating their relations of conflict and cooperation, and leading the decision-making processes along given pathways, the institutional rules provide the structure for political situations, allowing choices or inducing constraints at different moments in the decisionmaking process.

By focusing on institutions as both a product and conditioning factor for political conflicts and choices, while constraining and shaping the stakeholders' strategies and behaviors, it is possible to understand the central issues in political life: choice and constraint 2,3,4.

Social actors involved in the political power struggle create institutions, and understanding them requires analyzing the incentives, opportunities, and constraints that emerge for the various actors in this dispute ${ }^{2,3}$. The historical analysis of these processes is one of the central points in the neo-institutionalist approach, whose hard core is found in institutions with standardized relations, in which interactions between rules, stakeholders, interests, strategies, and power are identified and integrated in a given context, allowing to capture the complexity of real political situations $4,5,6$.

Drawing on primary sources, we sought to specifically unveil the interactions of conflict and cooperation between the actors, their strategies for influencing decisions, and the rules of the game conditioning the alternatives for action by the Executive and Legislative Branches.

We have divided our presentation into three parts: (1) a brief background on Health Surveillance at the Federal level in Brazil from the 19th century to 1999; (2) aspects pertaining to the former Health Surveillance Secretariat from 1990 to 1998; and (3) the political decision to create ANVISA in the 1998-1999 political context. We conclude with key observations on how this institution was created and its enormous relevance for the protection of the Brazilian population's health.

\section{Political/institutional evolution in Health Surveillance at the Federal level in Brazil: a synthesis}

Health Surveillance today can be viewed as an integrated set of legal, technical, inspection, information, education, and research actions aimed at exercising health-related control over activities, services, and the production and consumption chain entailing potential risk to health and the environment, thereby protecting and promoting the population's health 7,8,9. Historically, in Brazil this vast range of actions and interventions belonged to the public health sphere, under the responsibility of the Ministry of Health since its creation in 1953. Health Surveillance is currently part of the Unified National Health System (Sistema Único de Saúde - SUS) and is responsible for the health-related control of medicines, food, beverages, tobacco products, hygiene products and perfumes, cleaning products, medical, dental, and hospital equipment and materials, immunobiologicals, blood and blood products, human organs and tissues for use in transplantation, radioisotopes and radioactive drugs, and products involving any risk to health and obtained through genetic engineering. It also exercises health control over health services, ports, airports, and border stations, physical installations, equipment, technologies, environments, and processes involved in the production phases of these goods and products, and the destination of waste and the transportation and distribution of the above-mentioned products 10 .

Measures aimed at the inspection and control of the health environment in Brazil date far back in Brazil's history. It is beyond the scope of this article to describe the full historical evolution, however based on research by various authors $1,7,8,9,11,12,13$, Table 1 summarizes the most important political/institutional facts marking the history of Health Surveillance at the Federal level, from the country's Imperial period until the creation of ANVISA in 1999.

The intricate pathway of health control policies in Brazil shaped a profuse normative mosaic that expressed the political, health, and economic concerns of each given period in the country's history, with ups and downs and an effectiveness that fell short of its growing industrial and social complexity. Measures in response to isolated problems, lack of coordination among health measures, and lack of homogeneity and scope in government action at the national level, along with absence of specificity according to regional diversity, demonstrated the lack of an effective National Health Surveillance Policy. Such characteristics can be explained primarily by the historical weakness of the Brazilian state's roles in relation to public health. Even after the Ministry of Health was created its responsibilities remained extremely modest, given that it was confined to the most traditional and backward sector of the public administration, with scant funding and minimum political power to intervene.

The Brazilian Health Reform that gave rise to the SUS launched important institutional changes, especially beginning with the incorporation of the National Institute of Medical Care and Social Security (Instituto Nacional de Assistência 
Summary of the most relevant political and institutional facts in the history of Health Surveillance at the Federal level in Brazil (19th and 20th centuries).

\begin{tabular}{|c|c|c|}
\hline Period & Phases of government & Institutional facts \\
\hline 1808-1889 & Empire & $\begin{array}{l}\text { - Health control in ports as the main concern } \\
\text { - 1810; Purveyor's Regiment: medical police model } \\
\text { - 1820; Public Health Inspector's Office, Rio de Janeiro Port Authority. Other public health services: } \\
\text { municipal until } 1849 \\
\text { - 1885; Imperial Health Services Reform: land and maritime health services. Superior Public Health } \\
\text { Board: normative functions }\end{array}$ \\
\hline 1889-1930 & First Republic & 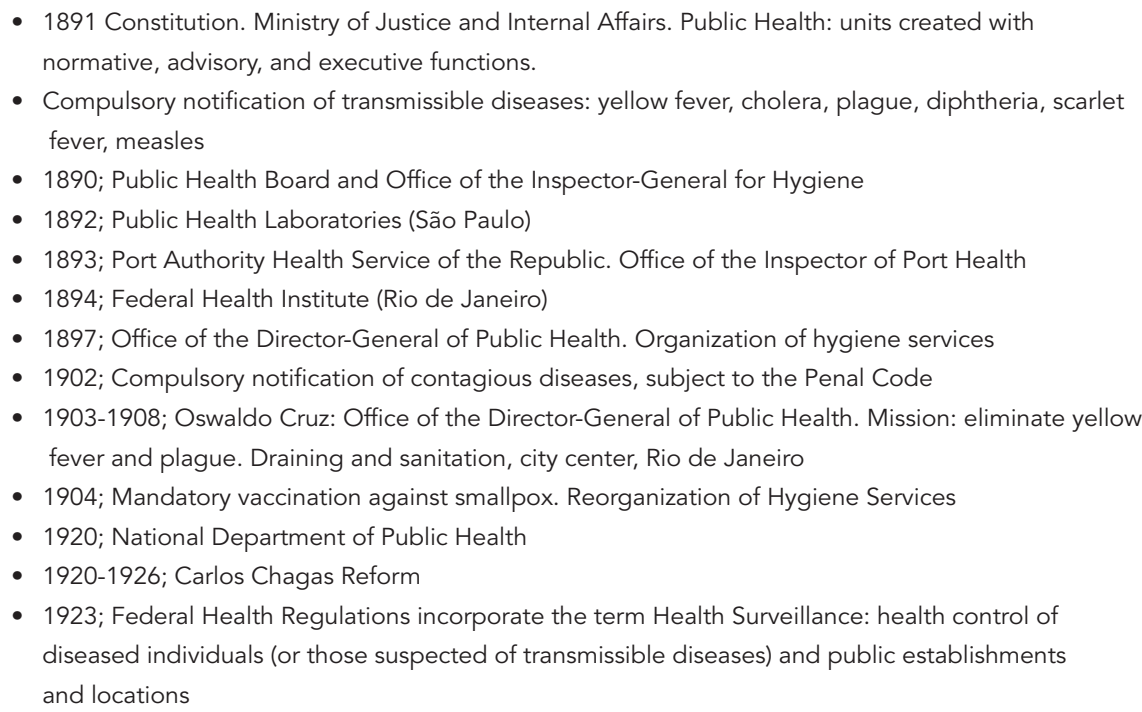 \\
\hline 1930-1945 & Vargas Government & $\begin{array}{l}\text { - 1937; Ministry of Education and Health. Definition of the fields of action of Health Surveillance. } \\
\text { Health control unified under the Port Health Service. Incorporation of recommendations by } \\
\text { international health agreements }\end{array}$ \\
\hline 1946-1963 & Democratic Republic & $\begin{array}{l}\text { - 1953; Ministry of Health } \\
\text { - 1954; Central Laboratory for the Control of Drugs and Medicines (LCCDM) } \\
\text { - 1961; National Public Health Code } \\
\text { - Central Laboratory for the Control of Drugs, Medicines, and Food (LCCDMA) }\end{array}$ \\
\hline 1964-1982 & $\begin{array}{l}\text { Military Regime and } \\
\text { Democratic Transition }\end{array}$ & $\begin{array}{l}\text { - Decree } 200 / 67 \text { ascribes responsibility to the Ministry of Health for formulating and coordinating } \\
\text { - He National Health Policy } \\
\text { and services } \\
\text { - } 1976-1977 \text {; National Health Surveillance Secretariat (SNVS) } \\
\text { - LCCDMA transferred to the Oswaldo Cruz Foundation. In 1981, transformed into the National } \\
\text { Institute for Quality Control in Health (INCQS) } \\
\text { - Important health control legislation enacted, still in force (Acts } 5,991 / 73,6,360 / 76, \text { and } 6,437 / 77 \\
\text { and Decree-Act 986/69) }\end{array}$ \\
\hline 1985-1994 & $\begin{array}{l}\text { New Republic; } \\
\text { José Sarney, Fernando } \\
\text { Collor, and Itamar Franco } \\
\text { Administrations }\end{array}$ & $\begin{array}{l}\text { - 1986; National Conference on Consumers' Health } \\
\text { - } 1988 \text { Federal Constitution establishes the universal right to health } \\
\text { - 1990; Unified National Health System (SUS) (Acts. 8,080/90 and 8,142/90) } \\
\text { - Consumer Defense Code (Act 8,078/90) } \\
\text { - 1992; Name of SNVS changed to Health Surveillance Secretariat (SVS) } \\
\text { - 1993; Incorporation of the National Institute for Medical Care and Social Security (INAMPS) into } \\
\text { the Ministry of Health } \\
\text { - 1994; Ministry of Health Ruling MS/GM 1,565/94 establishes guidelines for the National Health } \\
\text { Surveillance System (SNVS) }\end{array}$ \\
\hline 1995-1999 & $\begin{array}{l}\text { Fernando Henrique } \\
\text { Cardoso Administration }\end{array}$ & - 1999; National Health Surveillance Agency (Act 9,782/99) \\
\hline
\end{tabular}

Source: prepared by the authors. 
Médica da Previdência Social - INAMPS) into the Ministry of Health in 1993, which brought crucial changes to the field of public health, to the extent that unprecedented power resources were added to the renewed Ministry. Based on this strengthened position and changes in the field of political forces, in 1995 new directions materialized for the Health Surveillance Secretariat. These factors, combined with the international dissemination of new ideas on the increased state regulatory role, expressed in Brazil in the Program for Public Sector Administrative Reform 14, as well as the requirements of international trade agreements, were crucial to the drafting of a new Health Surveillance agenda.

\section{The 1990 s scenario}

The 1990s began with the opening of Brazil to imports in step with a radical deregulation of criteria for granting registration of products subject to Health Surveillance under the Ministry of Health project called Inovar (Innovate) 8,13. According to Federal Deregulation Program guidelines 15 related to state intervention in the market, the basic principles of Inovar were the restriction of government interference in companies and the creation of a product quality assurance system. While the first principle was expressed in the granting of product registration with no prior technical review, especially for medicines 8,13 , the second was never implemented. Revoked in 1993 on grounds that it was detrimental to the public health, the project aggravated the existing disorder in the Federal sphere of Health Surveillance 13.

A series of events, including various exposés of administrative improbity, administrative turnover, partisan political interference in naming individuals to various administrative positions, and pressure to grant product registration characterized the scenario in 1994, bringing to public light the chaotic situation of the Health Surveillance Secretariat. Newspaper stories (Folha de S. Paulo database, 1990-2000) featured suspicions concerning corruption, in addition to complaints by successive administrators who charged precarious funding, impediments to action, and political interference in decisions. However, no explicit clashes were noted between public and private agents, perhaps because both sides appeared to reap benefits from the corrosion of the Health Surveillance Secretariat.

In the mid-1990s, pork-barrel political tradeoffs, nepotism, and low technical capacity permeated the Health Surveillance Secretariat. Meanwhile, there was a significant expansion in Brazil's industrial and social complexity, interna- tional trade, pressure by economic blocks, and international trade competition. Problems related to inefficient health control thus multiplied.

Within this context, the "colonization" of the Health Surveillance Secretariat by private and partisan political interests began to bother the various interests. The industrial sector, which had always benefited from the inoperability of health control, now needed its agility and blessing to compete on the international market, given that quality adds value to a marketed product. Meanwhile, the Federal government, which had invariably sought to keep health control from interfering with the economic logic of those who backed its political projects, needed to project an image of institutional reliability and stability to bolster its image on the international market. In addition, since the new international trade rules required that government acts be predictable, it was crucial for the country to look trustworthy and secure to investors. Such premises are basic for understanding the period from 1995 to 1998 , marked at the domestic level by efforts towards economic stabilization and institutional governance.

This period witnessed the expansion of interactions between players from the Health Surveillance Secretariat's field of activity, including the Ministries of Finance and Foreign Relations, and especially between the Chamber of Foreign Commerce and Itamaraty (Foreign Relations), due to the prevalence of agreements signed within the sphere of the Southern Cone Common Market (MERCOSUL), especially for the harmonization of normative health control acts.

However, since government bureaucracies are notoriously slow to change, the Health Surveillance Secretariat persisted with its limited capacity to react to the demands for health control. Various tragedies occurred during this period, including 68 deaths at a hemodialysis clinic in Caruaru, Pernambuco, and 102 deaths at the Santa Genoveva Clinic in Rio de Janeiro. Meanwhile, pressure mounted from the industrial sector for more streamlined action by the Health Surveillance Secretariat and its total revamping along the lines of the U.S. Food and Drug Administration (FDA), claiming that the Secretariat's structure and work processes no longer met the objectives of an increasingly globalized and demanding market. In this sense, there were various converging opinions between the industrial sector and the Federal government that created the political opportunity to propose the creation of an autarquia, i.e., a public body with economic, technical, and administrative autonomy, although supervised under state tutelage (Folha de S. Paulo database, 1990-2000). 
Transforming the Health Surveillance Secretariat became the object of numerous discussions. Unsuccessful attempts were made by Health Minister Adib Jatene (1995-1996), including the pursuit of financial autonomy through cooperative agreements with international funding agencies, increased product registration taxes, and the formation of a task force to turn the Health Surveillance Secretariat into an autonomous body with regulatory capacity in keeping with international standards.

In 1995-1996, both Minister Jatene and Health Surveillance Secretary Elisaldo Carlini (1995-1997) were politically focused on creating the Federal Health Surveillance Agency (Agência Federal de Vigilância Sanitária - AGVISA). The time was ripe, with great interest on the part of the Ministry of State Administration and Reform (MARE) in introducing the guidelines of the Master Plan for Public Sector Reform and qualifying some Federal government bodies as executive agencies 1 .

Importantly, since the great Administrative Reform under the Getúlio Vargas Administration, strategic policies for economic development were invariably attributed to autonomous government bodies with the aim of safeguarding them from political lobbying (i.e., so-called bureaucratic insulation), while allowing them more streamlined decision-making and expert staff. Foundations and autarquias were thus created that aimed to intervene directly in economic relations and balance consumption and production, regulate importation and exportation, and expand the national infrastructure, thereby industrializing the country. The administrative reforms up until the Jânio Quadros Administration (1961) planned and ordered development by means of "islands of excellence", cut out of direct administration for state action in the economy. During Brazil's military governments, the "administration for development" model focused on state expansion in economic and social life, decentralization of public sector activities, and the creation of indirect administrative organizations for intervention especially in the economy 16.

The regulatory reform carried out by various countries in the 1980s and 1990s and launched by the United States in the 1970s was adopted particularly in Great Britain during the Thatcher Administration 17,18. In Brazil, the National Privatization Program (PND) launched in 1991 and expanded from 1995 onward provided the basis for privatization of state-owned companies and the implementation of the Master Plan for Public Sector Reform, which in broad strokes displayed four different sectors: a strategic core (Executive,
Legislative, and Judiciary Branches); exclusive state activities carried out by executive and regulatory agencies; non-exclusive services, in which the state acted in cooperation with non-state public organizations; and the sector producing goods and services for the market, i.e., the stateowned monopolies subject to privatization 14 .

Thus, the proposal for agencies to regulate activities provided by private parties once again prioritized the creation of technical bodies shielded from political lobbying, both to intervene in activities linked to economic development and to protect the interests of services users, thus comprising activities focused on the public interest 19 .

In this context, meetings between the Health Surveillance Secretariat, Ministry of Health, and Ministry of State Administration and Reform staff in 1996 resulted in a project for an executive agency called the AGVISA, containing the draft for a Provisional Measure to create an autarquia (scheduled for December 1996) and a preliminary bill of law with a career plan for AGVISA experts in health surveillance activities. Still, despite the highly critical assessment of the sector, the effort by its managers, and the demands by the principal representatives of the regulated sector, the initiatives for change in the Health Surveillance Secretariat failed to enter the Federal government's decision-making agenda.

The years 1996 and 1997 were especially turbulent for health in Brazil due to the sector's severe financial crisis, generating political friction between the Ministers of Health, Economics, and Planning. The main bone of contention lay in the Health Ministry's proposal to create the so-called Provisional Contribution on Movement or Transfer of Amounts and Financial Credits and Rights (CPMF) 20, fully earmarked for the National Health Fund, as a way of tackling the financial crisis; however, once again, the Finance Ministry suggested that the Health Ministry cut expenditures. The Health Minister's refusal to do so depleted his bargaining power and led to his resignation in 1996, followed by that of Health Surveillance Secretary Elisaldo Carlini in March 1997. Among a series of motives, the decisive factor was a clash with Argentina over Brazilian health control measures targeting foodstuffs and registration of medicines from that country. In short, based on these events, turning the Health Surveillance Secretariat into an executive agency disappeared from the Ministry of Health's agenda of priorities 1 .

The situation changed decisively in March 1998 when José Serra took over as Minister of Health, with great public backing. At the time, exposés of counterfeiting of medicines were pro- 
liferating in the mass media (Folha de S. Paulo database, 1990-200). In June 1998, several batches of the contraceptive Microvlar, manufactured by Schering, were found to be inert, leading to unwanted pregnancies in numerous women. Confirmation of the counterfeiting of the drug Androcur, used to treat prostate cancer, led to widespread insecurity as to the quality of drugs. The growing number of outraged press stories showed that drug counterfeiting was on Brazilian society's agenda, precisely during a Presidential election campaign.

Given the burgeoning demand for answers, Minister Serra took such measures as: sanctions against companies that produced, distributed, and marketed fake or inert medicines; issuing of normative acts; publicizing channels for lodging complaints; and in the Judiciary sphere, the creation of so-called Public Health Precincts to investigate health sector crimes. In addition, responding to the public outcry and media pressure, the National Congress passed Act. 9,677/98 21, altering provisions from Chapter III, Section VIII of the country's Penal Code, including the classification of heinous crimes against the public health, and Act 9,695/98 22, altering the classification of crimes related to counterfeiting and tampering with products subject to health surveillance.

The facts and events that came to light in 1998 demonstrate what sociologist Giddens 23 calls the "new moral climate" in political decision-making, placing governments and inspection agencies in a dilemma vis-à-vis risk. First, alarmism is often necessary, but corrosive. Meanwhile, reluctance to create alarm or to give in to interest groups causes indignation, since in many cases the population cannot (and will not) wait for inspection agencies to reach an opinion about the levels and types of risk involved in a given situation 19. Given this mismatch, Minister Serra adopted a strategy of acknowledging the problems in the Health Surveillance Secretariat, asking for the population's help in inspection and oversight, and announcing the creation of a new agency to deal with the problems. The President Cardoso meanwhile authorized all necessary measures to guarantee better quality of food and drugs in the country. The creation of a National Health Surveillance Agency became a government priority in the year 1998. Physician and administrator Gonzalo Vecina Neto took over as head of the Health Surveillance Secretariat to implement the institutional change 1 .

\section{Formulating the change}

The factors to be considered in the institutional change thus included the gravity of the situation for the country's public health, the limited governing capacity of the Health Surveillance Secretariat, especially in the area of medicines, and the need to adapt to the new state regulatory model and the requirements of international health agreements. Still, these problems had already been identified for some time. What really brought about the change?

As highlighted in the policy analysis literature, a determinant factor for an issue to enter the decision-making agenda and for a decision to actually be reached is the shaping of a favorable political conjuncture. In this sense, without a doubt the event that precipitated the decision was President Fernando Henrique Cardoso's need to strengthen his candidacy for reelection by responding to pressure from both public opinion and the business community. Added to this was the stance by Minister Serra, willing to tackle the problem politically by implementing a radical institutional change in the Health Surveillance Secretariat. The country had already experienced the creation of the National Electric Energy Agency (Agência Nacional de Energia Elétrica - ANEEL) in 1996 and the National Telecommunications Agency (Agência Nacional de Telecomunicações - ANATEL) in 1997, which were replicated for the National Petroleum Agency (Agência Nacional do Petróleo - ANP) in 1997 and subsequent agencies, in keeping with the specificities, objectives, and characteristics of the interface with society 19 .

However, the process involved difficult negotiations. It was not the aim of the Ministry of State Administration and Reform, even in the economic area, to turn the Health Surveillance Secretariat into a regulatory agency. Thus far, this expensive but politically powerful model had been designed exclusively for infrastructure areas that the Federal Government considered strategic. The turns in the decision-making process were clear: first, the proposal for an executive agency; then a specific regulatory agency for the area of food and drugs; and later, a regulatory agency limited to drugs. In the latter, the proposal involved a streamlined body with a focus on the object of public concern at that moment (drugs), either maintaining the other activities within the Health Surveillance Secretariat (which would continue to exist) or decentralizing them to the States and Municipalities, as the Ministry of State Administration and Reform and economic sectors wanted 1 .

However, over the course of the decisionmaking process the weight of the Health Surveil- 
lance Secretariat's “dependency path” became evident, given the improbability that its historically built field of action would be fragmented. Besides, as indicated by Immergut 2,3, an institution's structural elements tend to persist and influence its decision-making processes. In other words, while for the Ministry of State Administration and Reform and the Ministry of Finance the Health Surveillance Secretariat would have to adjust to the design of an executive agency with limited objectives, for the Secretariat itself the issue was to maintain and expand its attributions through a regulatory agency. The latter alternative meant autonomy granted by a mandate to the directors, in addition to expanding the scope, range of activity, and staff with respective job positions and pay scales. The choice was whether the response would be narrow, to solve the more pressing problem, or a far-reaching political decision, providing Health Surveillance with unprecedented power resources.

Based on the above, there were two opposing concepts clashing at the negotiating table, one favoring the "minimal state" and another the "necessary state", whereby among the existing demands, the state selects those it considers crucial for the preservation of the social order, and which thus, as indicated by Przeworski 24, have the type of apparatus that allows the state to do what must be done (and only that). This also meant additional expenditures for the Federal Government and granting characteristics with political power to an institution: financial and administrative autonomy and management stability. The controversy dragged on for days until the Ministry of Health sent the draft of a Provisional Measure to the President on December 12, 1998.

On December 30, President Cardoso submitted Provisional Measure 1,791/98 to the National Congress, thus launching the policy's legislative phase.

In Brazil, a Provisional Measure is a powerful lawmaking prerogative of the Executive Branch, which became strategic in the decision-making that was beginning in the National Congress. Recourse to a Provisional Measure rather than submitting a regular bill of law was due to the urgency in creating the agency and defining health surveillance taxes to be paid by companies for health control activities (crucial resources for the agency to fund its activities). However, these taxes were not to be approved by a Provisional Measure, but by an ordinary law that would have to be passed by December 30, 1998 (according to Brazil's fiscal year regime) in order to charge the taxes in 1999. This underlying practical factor determined the entire decision-making process in the Executive and Legislative Branches.
Importantly, during the passage of the Provisional Measure and enactment of the law creating ANVISA, President Cardoso had been reelected in the first round of the elections with $53.6 \%$ of the votes and enjoyed a broad support coalition in the National Congress. This political dispensation was extremely favorable for approval of the agency without altering structural aspects in its configuration and within the planned timeframe for its implementation.

No amendments were submitted during the regimental timeframe, and no restrictions were received from the Joint Committees on Admissibility and Constitutionality and Merit, with a favorable report issued by the rapporteur, Congressman Carlos Mosconi (member of the government party, PSDB, from the State of Minas Gerais) 25 . The parties named the Senators and Representatives that participated in the Special Joint Session on January 13, 1999, to discuss the Provisional Measure. Its speedy passage was due to the prior consensus between the Executive and the various party leaders, i.e., the Executive had the necessary Congressional support, and the Legislative Branch refrained from any move to veto.

Some 60 different lobby groups participated in the Congressional arena. Although the Executive had the support it needed in Congress, during this phase any potential veto points or windows of opportunity for filibustering might have prolonged the discussions or even led to impasses, given that this was a strategic moment for the industrial and corporatist lobbies to sway decisions in their favor.

In the days preceding approval of the Provisional Measure, a series of meetings included the various interested parties: companies, employees of the Health Surveillance Secretariat and the National Institute of Quality Control in Health (Instituto Nacional de Controle de Qualidade em Saúde - INCQS) of the Oswaldo Cruz Foundation (Fundação Oswaldo Cruz - FIOCRUZ), as well as party leaders. Having negotiated the conflictive points, a mutual trust agreement was signed. Congress would pass the Provisional Measure, while the Minister committed himself to drafting a new Provisional Measure to include the additional negotiated items. Provisional Measure 1,791/98 was thus passed on January 13, 1999, in the last session of the National Congress for the 1998 legislature, giving rise to Act 9,782/99, creating the National Health Surveillance Agency (ANVS), signed into law on January 26. The demands negotiated between the party leaders and the Administration were: compliance by the agency with the guidelines of the National Health Council; maintenance of the decentralization of 
health surveillance in the States and Municipalities; expansion of social control mechanisms; drafting and implementation of the generic drugs act; reduction of health surveillance taxes for small domestic companies; reallocation of Health Surveillance Secretariat employees; and preservation of the INCQS at FIOCRUZ. The following month, the above-mentioned agreement resulted in Provisional Measure 1.814/99, the first of a series of measures subsequent to the Act and issued during the implementation of ANVS (whose acronym was later changed to ANVISA).

Beginning with the enactment of the legislation, the challenge would be the capacity to implement the Agency in keeping with the objectives for which it had been created, because, as highlighted by Diniz ${ }^{26}$, although the state in Brazil decides, legislates, and regulates to a considerable degree, historically speaking it has proven powerless to achieve it goals.

\section{Final remarks}

In Brazil, the process of institutional change in Health Surveillance at the Federal level in the mid-1990s took place in a context of economic changes in the international arena, accompanied at the domestic level by the consolidation of democracy and its institutions, a trend toward economic stabilization, reorganization of political and social forces, radical restructuring of the Health System, and reform of the state apparatus.

The process further resulted in a growing mismatch between the intensification of international trade with rapid technological development and the Health Surveillance Secretariat's limited capacity to respond to urgent problems that required profound transformations in the regulation of public-private relations, new parameters to provide it with technical, social, and political credibility, and governing capacity over the sectors it was supposed to regulate. No less important for this outcome was the need for the government to transform its own structure vis-àvis pressure by national and international industrial sectors to define stable and predictable legal and technical rules for commercial transactions subject to health control.

The politicization of the health surveillance issue in the 1990s gradually gained space beginning in 1995, during the Cardoso Administration. Under Health Minister Jatene, the sector's strategic value was identified, and with it the need for decision-making autonomy, reduction of private interference, an expert technical staff, and regulatory capacity in keeping with modern technical standards, requirements that fit the prerogatives conferred by the executive agency model which had recently been introduced in Brazil by the Master Plan for Public Sector Reform.

However, the initiative did not take hold, since it was subsumed by the severe financial crisis that struck the Unified National Health System at that moment, sparking sharp disagreement between the Administration and Minister Jatene. Even despite factors favorable to the change such as the repetition of dramatic problems in healthcare establishments, the insistence of private players on the need for changes in the Health Surveillance Secretariat, the coalition in support of the Administration within the National Congress, and the interest by the Ministry of State Administration and Reform (in addition to international pressure), the situation remained undefined.

However, the situation changed in 1998: the proliferation of exposés on counterfeiting of medicines, the public's reaction, and the media's investigative role turned drug quality into a crucial national issue to be solved by the authorities, to the extent that it signaled the anachronism of the state's action, precisely during the Presidential election campaign. Given the accumulated problems, Minister Serra catalyzed the demands for solutions in the Health Surveillance Secretariat and became the main political player in the process leading to the creation of ANVISA. In the Executive, this process involved the principal agents and stakeholders in the issue, with the Ministries of Health, Finance, and Public Sector Reform vying for power and influence, while the diverging interests were neutralized during the negotiations to the point of materializing crucial aspects in the transformations proposed by the Health Surveillance Secretariat.

Key to the story was the identification (by the Administration and industrial sectors) of the need for a regulatory agency as the best option to respond technically and politically to the sector's issues. Thus, for the first time in the country, a format already created for the economy's strategic sectors was transposed to the social area.

The proposal to create ANVISA could have been submitted to Congress as an ordinary bill of law. However, the Executive chose to use a Provisional Measure on grounds of the urgency in passing the legislation, both for the creation of the agency and the health surveillance taxes to be charged in 1999, providing vital resources for the Agency to begin its activities. In other words, the fiscal year principle determined the deadline of December 30, 1998, for submitting the Provisional Measure to the National Congress and its subsequent enactment as law in the last session of the 1998 legislature, on January 13, 1999. 
Congress did not raise any vetoes to the Administration's proposal: on the contrary, there were decisive allies among the parties belonging to the support coalition. This result can be attributed to President Cardoso's reelection in the first round in October 1998, facilitating the creation of the Agency within the foreseen timeframe.

In conclusion, despite almost a decade of discussions on the need to transform Health Surveil- lance at the Federal level in Brazil, the institutional change that included the creation of ANVISA resulted from a specific political conjuncture in 1998-1999, allowing the political, technical, and social actors to introduce a change in the agenda, decide on it, and launch its implementation in an unusually short timeframe. This decision was one of the most important and irreversible milestones in the history of public health in Brazil.

\section{Resumo}

Este artigo examina o processo de decisão política envolvido na criação da Agência Nacional de Vigilância Sanitária (ANVISA) em 1999. Primeiro aborda os antecedentes da Secretaria de Vigilância Sanitária e a necessidade de sua modernização para adequar a qualidade dos produtos sob seu controle às exigências das demandas nacionais e internacionais. Em seguida, sob a perspectiva teórica do neoinstitucionalismo, analisa o contexto sócio-político do debate relativo às alternativas propostas para adequar a Vigilância Sanitária a novas regras congruentes com essas exigências, dando destaque ao processo de formulação da nova política, às arenas de decisão e aos atores com interesses no setor. A pesquisa foi realizada com base em farto material documental e jornalístico, acrescida de entrevistas com atores privilegiados. Conclui-se que na construção da ANVISA foi determinante a favorável conjuntura política nacional ao propiciar a correlação positiva de forças que, em um espaço de tempo em extremo curto (1998-1999) permitiu criar a primeira agência reguladora na área das políticas sociais no Brasil.

Vigilância Sanitária; Agência Nacional de Vigilância Sanitária; Políticas Públicas

\section{Contributors}

M. F. Piovesan planned and conducted the research, analyzed the results, and drafted the article. M. E. Labra contributed to the article with the theoretical and methodological framework, discussion of the conclussions, and final review. 


\section{References}

1. Piovesan MF. A construção política da Agência Nacional de Vigilância Sanitária [Master's Dissertation]. Rio de Janeiro: Escola Nacional de Saúde Pública, Fundação Oswaldo Cruz; 2002.

2. Immergut EM. Health politics: interests and institutions in Western Europe. Cambridge: Cambridge University Press; 1992.

3. Immergut EM. As regras do jogo: a lógica da política de saúde na França, na Suíça e na Suécia. Rev Bras Ciênc Soc 1996; 11:139-65.

4. Steinmo S, Thelen K, Longstreth F. Structuring politics. Historical institutionalism in comparative analysis. Cambridge: Cambridge University Press; 1992.

5. Labra ME. Análise de políticas, modos de policymaking e intermediação de interesses. Physis (Rio J) 1999; 2:131-66.

6. Labra ME. Padrões de formulação de políticas de saúde no Chile. Dados 2000; 1:153-82.

7. Costa EA. Vigilância sanitária. Proteção e defesa da saúde. São Paulo: Editora Hucitec/Sociedade Brasileira de Vigilância de Medicamentos; 1999.

8. Costa EA, Rozenfeld S. Constituição da vigilância sanitária no Brasil. In: Rozenfeld S, organizadora. Fundamentos da vigilância sanitária. Rio de Janeiro: Editora Fiocruz; 2000. p. 15-40.

9. Lucchese G. Globalização e regulação sanitária. Os rumos da vigilância sanitária no Brasil [PhD Thesis]. Rio de Janeiro: Escola Nacional de Saúde Pública, Fundação Oswaldo Cruz; 2001.

10. Brasil. Lei no. 9.782. Cria a Agência Nacional de Vigilância Sanitária, define o Sistema Nacional de Vigilância Sanitária, e dá outras providências. Diário Oficial da União 1999; 26 jan.

11. Costa NR. Lutas urbanas e controle sanitário. Origens das políticas de saúde no Brasil. Petrópolis: Editora Vozes; 1986.

12. Henriques CMP. A vigilância sanitária dos portos: experiência da prevenção à entrada da cólera no porto de Santos [Master's Dissertation]. São Paulo: Faculdade de Medicina, Universidade de São Paulo; 1992.

13. Souto AC. Saúde e política. A vigilância sanitária no Brasil (1976-1994) [Master's Dissertation]. Salvador: Instituto de Saúde Coletiva, Universidade Federal da Bahia; 1996.

14. Presidência da República. Plano diretor da reforma do estado. Brasília: Presidência da República; 1995.

15. Brasil. Decreto no. 99.179. Cria o Programa Federal de Desregulamentação, e dá outras providências. Diário Oficial da União 1990; 16 mar.
16. Lima Junior OB. As reformas administrativas no Brasil: modelos, sucessos e fracassos. Rev Adm Pública 1998; 49:5-30.

17. Ribeiro JM, Costa NR, Silva PLB. Política de saúde no Brasil e strategies regulatórias em ambientes de mudanças tecnológicas. Interface Comun Saúde Educ 2000; (6):61-84.

18. Villela AV, Maciel CS. A regulação do setor de infra-estrutura econômica: uma comparação internacional. Texto para discussão, 684. http://www. ipea.gov.br (accessed on 29/Sep/2002).

19. Cuéllar L. As agências reguladoras e seu poder normativo. São Paulo: Editora Dialética; 2001.

20. Brasil. Lei no. 9.311. Institui a Contribuição provisória sobre Movimentação ou Transmissão de Valores e de Créditos e Direitos de Natureza Financeira - CPMF, e dá outras providências. Diário Oficial da União 1996; 25 out.

21. Brasil. Lei no. 9.677. Altera dispositivos do Capítulo III do Título VIII do Código Penal, incluindo na classificação dos delitos considerados hediondos crimes contra a saúde pública, e dá outras providências. Diário Oficial da União 1998; 2 jul.

22. Brasil. Lei no. 9.695. Acrescenta incisos ao art. 1o da Lei no. 8.072, de 25 de julho de 1990, que dispõe sobre os crimes hediondos, e altera os Arts. 2o, 5o e 10o da Lei no. 6.437, de 20 de agosto de 1977, e dá outras providências. Diário Oficial da União 1998; 20 ago.

23. Giddens A, Pierson C. Conversas com Anthony Giddens - o sentido da modernidade. Rio de Janeiro: Editora FGV; 2000.

24. Przeworski A. Sobre o desenho do Estado: uma perspectiva agente x principal. In: Bresser-Pereira LC, Spink P, organizadores. Reforma do Estado e administração pública gerencial. Rio de Janeiro: Editora FGV; 1998. p. 39-73.

25. Senado Federal. Sessão Extraordinária Conjunta de 13 de janeiro de 1999. Aprovação da Lei no. 9.782/99 de criação da Agência Nacional de Vigilância Sanitária. Diário do Congresso Nacional 1999; 14 jan.

26. Diniz E. Governabilidade, democracia e reforma do Estado. In: Diniz E, Azevedo S, organizadores. Reforma do Estado e democracia no Brasil. Brasília: Editora UnB/Escola Nacional de Administração Pública; 1997. p. 19-53.

Submitted on $08 /$ Aug/2005

Final version resubmitted on 30/Oct/2006 Approved on 04/Dec/2006 